\title{
Firm-level Inefficiency in Post-transition Economies
}

\section{Valerija Botrić}

The Institute of Economics, Zagreb, Croatia

\section{Abstract}

Firms in post-transition economies are frequently considered less efficient than those in more advanced market economies. By relying on the World Bank Enterprise Survey for the year 2019, firm-level technical inefficiency is estimated by the stochastic frontier analysis method for a sample of European post-transition countries. To be precise, the analysis included Albania, Bosnia and Herzegovina, Croatia, Czechia, Estonia, North Macedonia, Poland, Serbia, and Slovenia. Furthermore, the factors contributing to the firm-level inefficiency are explored in a comparative setting. The effects of the international orientation of the firm, foreign ownership, doing business with the government sector, presence of informal competitors, innovation activity, manager experience, and the age of the firm on the technical inefficiency are estimated. Results show that although some factors are common to a subsample of countries, not a single factor is significant in all the analysed economies.

Keywords: firm inefficiency, post-transition economies, stochastic frontier analysis JEL classification: D29, L25

Paper type: Research article

Received: Mar 10, 2021

Accepted: Jun 23, 2021

DOI: 10.54820/FKSQ7558 


\section{Introduction}

While relative inefficiency of socialist firms was a frequent topic in the early transition studies, the literature is scarce on the subject in the post-transition period. It was generally assumed that through privatization processes and the establishment of new privately-owned firms, private owners would be able to elicit more effort from managers than the state was able in the previous system (Brada et al., 1997). Thus, it was assumed that productivity would catch up and relative inefficiency problems would eventually disappear. Indeed, by relying on the macroeconomic data, Deliktas et al. (2005) reported a 1.8 percent average annual rate of growth in technical efficiency in transition countries during the 1991-2000 period. At the same time, they did not find evidence of technological progress, as the average annual technical change for the same period was -4.3 percent.

since all post-transition economies have successfully developed market structures ${ }^{1}$, it can easily be assumed that the market mechanisms are in place and firms, to a large extent, operate efficiently. Yet, Stubelj et al. (2017) claim that early transition transformation theorists frequently mixed the goals and means of transition in a sense that they viewed privatisation as a goal in itself, rather than as a means to achieve goals, i.e., more competitive, more innovative and long-term competitive firms. Indeed, many international comparisons provide evidence of persisting country (Mihaljek, 2018; Jakšić et al., 2020) and firm-level productivity gaps (Botrić et al., 2017) of post-transition to advanced market economies.

Studies frequently focus on the competitiveness of post-transition economies (Bierut et al., 2017; Gilbert et al., 2018; Rusu et al., 2017). European Commission (2019) data reveal that the New Member States are still below the Old Member States when it comes to many aspects of competitiveness. Thus, it seems that transformed economic systems still do not provide adequate support for the business sector to achieve its full potential.

Inefficiencies at the global economy level are usually associated with generic terms such as lack of adequate structural reforms (Rodrik, 2017; Crespy et al., 2019), institutional inadequacy (Ledeneva et al., 2021; Hernández et al., 2021), corruption (Aidis et al., 2012; Sandholtz et al., 2007). However, firm-level inefficiency studies are relatively scarce in post-transition European economies. Piesse et al. (2000) analyse inefficiencies of Hungarian firms in the early phases of transition and attribute them to overcapitalization, subsidies, and excessive management costs, while firms that had established export markets were more efficient. Kravtsova (2008) analyses firmlevel inefficiencies in Bulgaria, Estonia, Hungary, Poland, and Romania and find that the average technical efficiency of foreign firms is higher, but only in some sectors. Krammer (2015) compares inefficiencies in transition and developed economies and suggests that good institutions, regardless of operationalization choices, positively affect productivity levels. However, greater ease of doing business is the only institutional variable having a positive impact on both productivity and the relationship between productivity and spillovers across the economy.

Technical inefficiencies in the recent literature are more frequently analysed in the case of developing economies. For example, Khalifah (2013), in the analysis of the automobile industry in Malaysia, finds that vertical integration, quality of human capital, foreign ownership, and net import intensity are significant determinants of technical efficiency. Esquivias et al. (2020), on the example of firms in Indonesia, in

\footnotetext{
1 In order to assess various aspects of transition, EBRD initiated a set of indicators in 1997 (https://www.ebrd.com/our-values/transition.html). Based on these assessments, the transition period is over in the countries analyzed in this paper.
} 
addition to factors such as foreign ownership, international activity (export-import), and firm size, emphasize that if firms are operating in less competitive sectors, they will have higher technical efficiency. Lemi et al. (2020), on the example of firms in Ethiopia and Kenya, confirm the positive relationship between exporting and technical efficiency but do not find a significant influence of foreign ownership. Although different studies explore similar factors, the literature has not yet found a unique set of factors significant for firm-level inefficiencies across the countries.

The paper addresses the following gaps in the literature. To the best knowledge of the author, this is the first attempt to assess firm-level inefficiencies in a comparative perspective in post-transition economies. Furthermore, the inefficiency estimates consider the size of the enterprise, which has not been frequently accounted for in previous estimates for the analysed economies even in the early phases of transition. Additionally, factors contributing to firm inefficiency are explored, and differences across the countries are analysed.

The structure of the paper is following. The next section presents methodology and data sources, followed by the section containing the presentation of the results. In the discussion, section results are interpreted within a wider context, while the last section offers conclusions.

\section{Data sources and methodology}

The empirical analysis is focused on firm-level data from Albania, Bosnia and Herzegovina, Croatia, Czechia, Estonia, North Macedonia, Poland, Serbia, and Slovenia. The choice of the countries in the sample is guided by the availability of the data, as provided by The World Bank Enterprise Survey2. The same questionnaire is administered in all the countries, and the data is collected based on face-to-face interviews with managers containing information on a wide range of standard firm characteristics. The sample covers both the manufacturing and service sector but does not include companies that are ruled by government price regulations and state-owned enterprises. Since productivity and efficiency can be significantly erratic in the first few years of firm operations, we focus only on the well-established firms. This has been achieved by relying on the Enterprise Survey panel data for the 2009-2019 period (entailing 3 waves of the Survey) but retaining only the firms' data for 2019 in the empirical analysis.

The inefficiency factors are explored within a two-stage approach. In the first stage, by relying on stochastic frontier analysis and traditional Cobb-Douglas production function, technical inefficiency scores are estimated. The SFA approach assumes that firms operating on the frontier are fully technically efficient firms, while it measures inefficiency by computing the distance of firms from the frontier. Specifically, the following equation has been estimated:

$$
\ln Y_{i}=\beta_{0}+\beta_{1} \ln K_{i}+\beta_{2} \ln L_{i}+\left(V_{i}-U_{i}\right)
$$

The variables used to proxy the firm characteristics rely on Frances et al. (2020). Thus, the variables used to estimate the inefficiency scores are:

- $Y_{i}$ or value added is derived as the difference between the value of sales and the annual cost of inputs for each firm

- $\mathrm{K}_{\mathrm{i}}$ - machinery, vehicles, and equipment of the firm

- $\mathrm{L}_{i}$ - the number of workers in the firm

2 Detailed information about the Survey can be found on https://www.enterprisesurveys.org/en/data. 
- $V_{i}$ - error term for firm i

- $U_{i}$ - a non-negative random variable for firm i, accounting for technical inefficiency in the production function

If $U_{i}$ is equal to zero, it can be concluded that the firm is technically efficient at its maximum output level given the inputs used. If $U_{i}$ is greater than zero, the firm is technically inefficient. Intuitively, inefficiencies can only take positive values as no firm can be any more efficient than the frontier. It has to be, however, noticed that this limitation is set by design, and in the case of a highly heterogeneous withincountry sample, such methodological constraints can influence the average inefficiency level.

Efficiency is strongly related to economies of scale, making the size of the enterprise an important moderating factor (Khalifah, 2013). Thus, we model the mean of the inefficiency term as a linear function of a set of covariates that specify whether the enterprise is micro (less than 5 employees), small (between 5 and 19 employees), medium (between 20 and 99 employees) or large (more than 100 employees). The estimates are performed for each analysed country, so they implicitly assume the joint production frontier within the economy, a very strict assumption. Since the structure of economies differs, a comparison of average inefficiencies between the analysed countries does not seem plausible.

In the second stage, we investigate factors contributing to the estimated inefficiency. We investigate whether the following firm characteristics are relevant for firm inefficiency:

- Export orientation. It is widely believed that outward orientation is a stimulus to firms' productive efficiency (Brada et al., 1997; Lemi et al., 2020; Mazorodze, 2020). Wagner (2012) gives an overview of the literature and summarizes that exporters are more productive than non-exporters.

- Whether a firm has an internationally-recognized quality certification is an additional dummy capturing the international orientation of the firm. Following similar argumentation as for export orientation, it is assumed that those firms who invested in certification are more focused on achieving efficiency.

- Foreign ownership is a dummy variable taking value 1 if the firm has more than 51 percent of the ownership in foreign hands. Lu et al. (2017) suggest important externalities in the form of superior technology, knowledge, managerial expertise, and scale effects related to foreign ownership.

- Foreign technology is a dummy variable taking value 1 if a firm uses technology licensed from a foreign-owned company. Todo et al. (2016) find that a more extensive network of suppliers stimulates knowledge diffusion, which improves the firm's productivity and innovation capabilities.

- Age of the firm. Charoenrat et al. (2013) find that firm size, firm age, skilled labour, ownership characteristics, and location significantly affect the technical inefficiency of production in the Thai manufacturing sector.

- Literature suggests a positive link between innovation and productivity (Morris, 2018). To address this in the empirical estimates, a dummy variable is included that takes value 1 if the firm introduced new products/services over the last 3 years.

- The positive answer to the question of whether the firm secured or attempted to secure a government contract during the last fiscal year captures the connection to the government sector, an important segment of doing business in post-transition societies. It is assumed that work for the government sector exerts less pressure on the firm efficiency. 
- Whether a firm has informal competitors is a dummy variable that captures a general assessment of the market the firm operates in. The informal sector is perceived to be widespread in post-transition societies (Williams et al., 2018), but this does not mean that all segments of the economy are equally affected. It is assumed that those who are operating in markets with higher informality would be more inclined to less efficient business operations because efficiency is not the most important criterion for successful competition in such markets.

- Manager experience is captured through the years of experience within the same sector. It is assumed that more experienced managers will be able to organize business activities in a more efficient way. Chemmanur et al. (2009) find that higher ability managers may select better firm projects, achieving higher investments in R\&D that could increase efficiency.

Enterprise Survey data are available in local currency units. In order to ensure the comparability of the estimates across the analysed countries, nominal variables have been converted to EUR using the Eurostat data on annual exchange rates corresponding to the fiscal year reported in the Enterprise Survey. The final specification takes the following form:

$$
\begin{aligned}
\text { inefficiency }_{i} & =\alpha+\beta_{1} \text { firmage }_{i}+\beta_{2} \text { foreign }_{i}+\beta_{3} \text { ftechnology }_{i} \\
& +\beta_{4} \text { int_certificate }_{i}+\beta_{5} \text { innovator }_{i}+\beta_{6} \text { exporter }_{i} \\
& +\beta_{7} \text { government }_{i}+\beta_{8} \text { informal }_{i}+\beta_{9} \text { manager }_{i}+\varepsilon_{i}
\end{aligned}
$$

As the values of the dependent variable are bounded to take values of 0 and above, the equation is estimated by relying on Tobit maximum likelihood using robust standard errors to account for heteroscedasticity. Results are presented in the following section.

\section{Results}

We start by presenting the first stage estimates in Table 1. We present the production function baseline for the inefficiency estimates, focusing only on the production factors coefficients.

Table 1

Production Function Coefficients across the Countries

\begin{tabular}{lccccccccc}
\hline Variables & Albania & B\&H & Croatia & Czechia & Estonia & $\begin{array}{l}\text { North } \\
\text { Maced. }\end{array}$ & Poland & Serbia & Slovenia \\
\hline \multirow{2}{*}{ Labour } & $1.30^{* * *}$ & $1.17^{* * *}$ & $0.74^{* * *}$ & $0.94^{* * *}$ & $0.97^{* * *}$ & $0.93^{* * *}$ & $1.01^{* * *}$ & $0.90^{* * *}$ & $0.69^{* * *}$ \\
\multirow{2}{*}{ Capital } & $(0.30)$ & $(0.27)$ & $(0.11)$ & $(0.08)$ & $(0.18)$ & $(0.17)$ & $(0.14)$ & $(0.19)$ & $(0.11)$ \\
& 0.04 & -0.05 & $0.23^{* * *}$ & $0.25^{* * *}$ & $0.23^{* * *}$ & $0.13^{* *}$ & 0.03 & $0.14^{* * *}$ & $0.11^{* *}$ \\
\multirow{2}{*}{ Gamma } & $(0.07)$ & $(0.07)$ & $(0.05)$ & $(0.03)$ & $(0.04)$ & $(0.05)$ & $(0.05)$ & $(0.05)$ & $(0.04)$ \\
\hline
\end{tabular}

Source: author's estimates based on Enterprise Survey data.

It has to be emphasized that the literature suggests that stochastic frontier analysis is appropriate if the estimated value of $y$ is closer to 1 . The value of $y$ close to zero also implies that the production function is biased by uncontrolled factors or noises. A lower value of $y$ reflects a lower impact from the technical inefficiency component. Based on the findings, we can conclude that the inefficiency estimates are relatively unstable. We attribute this to relatively low numbers of observations per country. Yet, inflating the sample by pooling the country data would introduce even 
more heterogeneity. Thus, we proceed with estimating inefficiency factors, acknowledging the fact that the quality of estimated inefficiencies could and should be improved in future research endeavours.

Regardless of this fact, we can notice from the data in Table 1 that in all analysed countries dominant factor of production is labour. This is emphasized in Albania, Bosnia, and Herzegovina, and Poland, where capital did not even significantly enter the estimated production function. Although such findings were expected, the magnitude of the estimated coefficients implies strong reliance on the labour intensity in production.

In order to compare different factors across the analysed economies, we focus on the marginal effect of the covariates on the observed outcome. These results are presented in Table 2. The full set of Tobit equation estimates are presented in Appendix Table A1.

Table 2

Marginal Effects of Factors Explaining Firm Inefficiency across Countries

\begin{tabular}{|c|c|c|c|c|c|c|c|c|c|}
\hline Variables & Albania & B\&H & Croatia & Czechia & Estonia & $\begin{array}{l}\text { North } \\
\text { Maced. }\end{array}$ & Poland & Serbia & Slovenia \\
\hline Firm age & $\begin{array}{c}0.003 \\
(0.003)\end{array}$ & $\begin{array}{c}0.006^{* * *} \\
(0.001)\end{array}$ & $\begin{array}{c}-0.001^{* *} \\
(0.000)\end{array}$ & $\begin{array}{l}0.001^{* *} \\
(0.001)\end{array}$ & $\begin{array}{l}-0.000 \\
(0.001)\end{array}$ & $\begin{array}{l}-0.001 \\
(0.001)\end{array}$ & $\begin{array}{c}-0.006 \\
(0.004)\end{array}$ & $\begin{array}{l}-0.001 \\
(0.001)\end{array}$ & $\begin{array}{c}-0.004^{* * *} \\
(0.001)\end{array}$ \\
\hline $\begin{array}{l}\text { Foreign } \\
\text { ownership }\end{array}$ & $\begin{array}{l}-0.014 \\
(0.118)\end{array}$ & $\begin{array}{c}0.140 \\
(0.093)\end{array}$ & $\begin{array}{c}-0.059^{* *} \\
(0.025)\end{array}$ & $\begin{array}{l}0.036^{* *} \\
(0.018)\end{array}$ & $\begin{array}{l}-0.123 \\
(0.104)\end{array}$ & $\begin{array}{c}0.031 \\
(0.037)\end{array}$ & $\begin{array}{c}-0.308^{* *} \\
(0.127)\end{array}$ & $\begin{array}{l}-0.127^{*} \\
(0.067)\end{array}$ & $\begin{array}{l}-0.123 \\
(0.091)\end{array}$ \\
\hline $\begin{array}{l}\text { Foreign } \\
\text { technology }\end{array}$ & $\begin{array}{c}0.047 \\
(0.204)\end{array}$ & $\begin{array}{c}-0.204^{* * *} \\
(0.063)\end{array}$ & $\begin{array}{c}-0.065^{* * *} \\
(0.020)\end{array}$ & $\begin{array}{c}0.020 \\
(0.017)\end{array}$ & $\begin{array}{c}0.078 \\
(0.108)\end{array}$ & $\begin{array}{l}-0.011 \\
(0.028)\end{array}$ & $\begin{array}{c}0.033 \\
(0.116)\end{array}$ & $\begin{array}{l}-0.001 \\
(0.088)\end{array}$ & $\begin{array}{l}-0.131^{*} \\
(0.071)\end{array}$ \\
\hline $\begin{array}{l}\text { International } \\
\text { certification }\end{array}$ & $\begin{array}{c}0.257 \\
(0.175)\end{array}$ & $\begin{array}{l}-0.089 \\
(0.066)\end{array}$ & $\begin{array}{c}-0.067^{* *} \\
(0.026)\end{array}$ & $\begin{array}{c}0.017 \\
(0.014)\end{array}$ & $\begin{array}{l}0.161^{*} \\
(0.096)\end{array}$ & $\begin{array}{l}-0.014 \\
(0.027)\end{array}$ & $\begin{array}{l}-0.093 \\
(0.090)\end{array}$ & $\begin{array}{l}-0.046 \\
(0.089)\end{array}$ & $\begin{array}{c}-0.200^{* *} \\
(0.077)\end{array}$ \\
\hline Innovator & $\begin{array}{l}-0.193 \\
(0.125)\end{array}$ & $\begin{array}{l}0.169 * * \\
(0.069)\end{array}$ & $\begin{array}{c}0.021 \\
(0.026)\end{array}$ & $\begin{array}{l}0.027^{* *} \\
(0.012)\end{array}$ & $\begin{array}{c}0.010 \\
(0.089)\end{array}$ & $\begin{array}{l}-0.056^{*} \\
(0.028)\end{array}$ & $\begin{array}{c}0.058 \\
(0.072)\end{array}$ & $\begin{array}{l}-0.092 \\
(0.083)\end{array}$ & $\begin{array}{c}0.035 \\
(0.078)\end{array}$ \\
\hline Exporter & $\begin{array}{c}0.007^{* * *} \\
(0.002)\end{array}$ & $\begin{array}{l}0.002^{* *} \\
(0.001)\end{array}$ & $\begin{array}{c}-0.001^{* *} \\
(0.000)\end{array}$ & $\begin{array}{c}0.001^{* * *} \\
(0.000)\end{array}$ & $\begin{array}{c}0.001 \\
(0.001)\end{array}$ & $\begin{array}{r}-0.000 \\
(0.000)\end{array}$ & $\begin{array}{c}-0.005^{* * *} \\
(0.001)\end{array}$ & $\begin{array}{c}0.000 \\
(0.001)\end{array}$ & $\begin{array}{c}-0.003^{* *} \\
(0.001)\end{array}$ \\
\hline $\begin{array}{l}\text { Government } \\
\text { contract }\end{array}$ & $\begin{array}{l}-0.170 \\
(0.192)\end{array}$ & $\begin{array}{c}0.023 \\
(0.093)\end{array}$ & $\begin{array}{l}-0.042 \\
(0.033)\end{array}$ & $\begin{array}{c}0.008 \\
(0.015)\end{array}$ & $\begin{array}{c}0.122 \\
(0.123)\end{array}$ & $\begin{array}{l}-0.058 \\
(0.036)\end{array}$ & $\begin{array}{l}-0.308^{*} \\
(0.175)\end{array}$ & $\begin{array}{c}0.071 \\
(0.070)\end{array}$ & $\begin{array}{l}-0.009 \\
(0.071)\end{array}$ \\
\hline $\begin{array}{l}\text { Informal } \\
\text { competitors }\end{array}$ & $\begin{array}{l}-0.054 \\
(0.142)\end{array}$ & $\begin{array}{c}0.049 \\
(0.074)\end{array}$ & $\begin{array}{l}-0.056 \\
(0.035)\end{array}$ & $\begin{array}{l}-0.009 \\
(0.015)\end{array}$ & $\begin{array}{l}-0.027 \\
(0.104)\end{array}$ & $\begin{array}{c}0.004 \\
(0.027)\end{array}$ & $\begin{array}{c}0.070 \\
(0.112)\end{array}$ & $\begin{array}{l}-0.047 \\
(0.115)\end{array}$ & $\begin{array}{c}0.003 \\
(0.094)\end{array}$ \\
\hline $\begin{array}{l}\text { Manager } \\
\text { experience }\end{array}$ & $\begin{array}{l}0.014^{*} \\
(0-007)\end{array}$ & $\begin{array}{l}-0.004 \\
(0.003) \\
\end{array}$ & $\begin{array}{c}0.002 \\
(0.002) \\
\end{array}$ & $\begin{array}{l}-0.000 \\
(0.001) \\
\end{array}$ & $\begin{array}{c}0.003 \\
(0.004) \\
\end{array}$ & $\begin{array}{l}-0.001 \\
(0.002) \\
\end{array}$ & $\begin{array}{c}-0.003 \\
(0.005) \\
\end{array}$ & $\begin{array}{c}0.003 \\
(0.003) \\
\end{array}$ & $\begin{array}{l}0.006^{* *} \\
(0.003) \\
\end{array}$ \\
\hline
\end{tabular}

Source: author's estimates based on Enterprise Survey data.

The results suggest that factors contributing to relative firm inefficiencies differ among the countries, as there is no single factor that is significant in all analysed economies. Exporter status is mostly negatively related to firm inefficiency. However, in some countries, exporters are more likely to be inefficient (Albania, Bosnia and Herzegovina, Czechia), in others, less likely (Croatia, Poland, and Slovenia). A firm that relies on foreign technology is less likely to be inefficient (Bosnia and Herzegovina, Croatia, and Slovenia). This is supported by an international certification (Croatia and Slovenia), but surprisingly firms in Estonia with international certificates are more likely to be inefficient. Foreign ownership exerts a positive influence on firm efficiency in Croatia, Poland, and Serbia but contributes to the firm inefficiency in Czechia. Overall, it seems that different aspects of firm internationalization are positively associated with firm efficiency in Croatia and Slovenia.

Firm age also exerts different impacts across analysed economies. In Croatia and Slovenia, more mature firms are more efficient, while the opposite holds for firms in Czechia and Bosnia and Herzegovina. It is interesting to notice that within-sector management experience is not significant in most of the countries but does significantly contribute to firm inefficiency in Albania and Slovenia. 
Finally, for the transition countries, it has been frequently emphasized that the strong reliance on the government sector indicates still rather weak market elements in the economy. At the same time, due to institutional rigidities, there is a large prevalence of the shadow economy, which might impede the efficiency of doing business. It is encouraging to show that we do not find any significant evidence that firms that have to deal with informal competitors are less efficient. Related to ties with the government sector, we find evidence of a significant relationship only in the case of Poland, where firms working with the government are less likely to be relatively more inefficient. This would suggest that even if there is still a high share of the government sector in some of the analysed economies, it is not related to the inefficiencies of the private sector firms.

\section{Discussion}

The results presented in this paper are in accordance with previous findings from the literature and, in the particular existing literature on transition economies, suggesting lasting effects of some of the factors contributing to firm inefficiency. For example, results confirm that exporting firms are less likely to be inefficient (Piesse et al., 2000). This has been confirmed by the present paper in the case of Croatia, Poland, and Slovenia also for the post-transition period.

Our results also corroborate findings that factors exert different effects across the countries. For example, Kravstova (2008) suggested that foreign firms are more efficient than domestic counterparts in Hungary and Poland and less efficient in Bulgaria, Romania, and Estonia. Our results also suggest a positive effect of foreign ownership on firm efficiency in the case of Poland, but we do not find a significant effect for Estonia. Since the transition path was different across the analysed economies, it was highly expected that also in the post-transition period, factors contributing to firm-level inefficiency would differ.

Although in our case, foreign firms are more likely to be efficient in more countries, the mechanism for creating relative inefficiencies is revealed through the specific motive for foreign investment. Specifically, foreign investors might be more interested in access to local markets than in organizing the production process more efficiently than local firms. Sari et al. (2016) suggest that the reason foreign-owned firms are less efficient than average players on the market is due to their allocation of more resources (wastefully) to gain additional market participation. This could be more important in the economies where the informal sector is widespread and doing business is related to establishing adequate (political) ties.

Although some studies suggest that innovative firms are more productive in both the manufacturing and services sectors (Morris, 2018), the impact of innovation on firm performance depends on the relative success of each innovation project. It could be the case that most of the innovation in the analysed countries is new to the market and not radically new. In these cases, the potential to exploit the benefits of innovation is limited by the size of the local market. Also, in the case of radical innovations, the effect of efficiency could even initially be negative, as it could demand the firm's complete reorganisation of existing production processes.

Foreign technology transfer does not necessarily entail state-of-the-art machinery or knowledge. Indeed, when there is limited competition on the local markets and technology transfer costs are high (because of institutional or availability of adequate human capital constraints, for example), technology upgrade is not equal to catching up the level of advanced economies (Kravstova, 2008). Our results do find a positive association between foreign technology and efficiency in 
some countries. In others, precise mechanisms failing to support this channel for efficiency increase should be further explored.

The present paper does not differentiate between the specificities of each industry, which can certainly have an effect on the overall results. This approach has been taken due to the limited observations available for each country. Thus, the relative inefficiency of each firm is measured to the global economy production frontier. Yet, it is more likely that each industry has its own production frontier. To overcome this caveat, future research efforts could be focused on a single industry.

\section{Conclusion}

The paper is focused on the comparative analysis of firm-level inefficiencies in posttransition economies. By relying on firm-level Enterprise Survey data from Albania, Bosnia and Herzegovina, Croatia, Czechia, Estonia, North Macedonia, Poland, Serbia, and Slovenia, the paper identifies inefficiency and explores factors contributing to firm-level inefficiency.

The analysis suggests that firm-level inefficiency varies across the analysed countries. At the same time, the analysis revealed that in the post-transition period, the dominant factor of production remains labour. Competitiveness based on labour intensity thus remains the dominant firm strategy in post-transition economies.

Different forms of international relations are connected to firm-level inefficiencies, although the specific form varies across the countries. In some cases, foreign ownership is important; in other exporting experience of the firm, the use of foreign technology or international certification also play an important role. Thus, it seems that firms that have access to wider markets are at the same time more likely to be efficient. Those strictly oriented towards local markets are facing less-demanding markets, which is probably connected to smaller demand for higher efficiency.

We refrain from making firm conclusions based on the results presented in the paper because of the small sample sizes in all analysed countries. Due to relatively scarce findings in the literature on the same subject, further investigation is needed. Country studies covering larger datasets, though not enabling a comparative perspective, could still complement the findings presented in the present paper.

\section{References}

1. Aidis, R., Estrin, S., Mickiewicz, T. M. (2012), "Size matters: Entrepreneurial entry and government", Small Business Economics, Vol. 39 No. 1, pp. 119-139.

2. Bierut, B. K., Kuziemska-Pawlak, K. (2017), "Competitiveness and export performance of CEE countries", Eastern European Economics, Vol. 55 No. 6, pp. 522-542.

3. Botrić, V., Božić, Lj., Broz, T. (2017), "Explaining firm-level total factor productivity in post-transition: manufacturing vs. services sector", Journal of International Studies, Vol. 10 No. 3, pp. 77-90.

4. Brada, J. C., King, A. E., Ma, C. Y. (1997), "Industrial Economics of the Transition: Determinants of Enterprise Efficiency in Czechoslovakia and Hungary", Oxford Bulletin of Economics and Statistics, Vol. 49 No.1, pp.104-127.

5. Charoenrat, T., Harvie, C., Amornkitvikai, Y. (2013), "Thai manufacturing small and medium sized enterprise technical efficiency: evidence from firm-level industrial census data", Journal of Asian Economics, Vol. 27 (August), pp. 42-56.

6. Chemmanur, T. J., Paeglis, I., Simonyan, K. (2009), "Management quality, financial and investment policies, and asymmetric information", Journal of Financial and Quantitative Analysis, Vol. 44 No. 5, pp. 1045-1079.

7. Crespy, A., Venheuverzwijn, P. (2019), "What 'Brussels' means by structural reforms: empty signifier or construvtive ambiguity?", Comparative European Politics, Vol. 17 No.1, pp. 92-111. 
8. Deliktas, E., Balcilar, M. (2005), "A Comparative Analysis of Productivity Growth, Catch-Up, and Convergence in Transition Economies", Emerging Markets Finance and Trade, Vol. 41 No.1, pp. 6-28.

9. Esquivias, M. A., Harianto, S. K. (2020), "Does competition and foreign investment spur industrial efficiency? Firm-level evidence from Indonesia", Heliyon, Vol. 6 No. 8, pp. 110.

10. European Commission (2019), "The EU Regional Competitiveness Index 2019", available https://ec.europa.eu/regional_policy/sources/docgener/work/2019_03_rci2019.pdf (14 April 2021)

11. Frances, D. S., Karalashvili, N., Maemir, H., Meza, J. R. (2020), "Measuring total factor productivity using the Enterprise Survey: A methodological note", available at: https://openknowledge.worldbank.org/bitstream/handle/10986/34913/MeasuringTotal-Factor-Productivity-Using-the-Enterprise-Surveys-A-Methodological-Note.pdf (14 April 2021)

12. Gilbert, J., Muchová, E. (2018), "Export competitiveness of Central and Eastern Europe since the enlargement of the EU", International Review of Economics \& Finance, Vol. 55, pp. 78-85.

13. Hernández, V., Nieto, M. J., Rodríguez, A. (2021), "Home country institutions and export of firms in transition economies: Do innovation matter?", Long Range Planning, forthcoming.

14. Jakšić, S., Erjavec, N., Cota, B. (2020), "Export and total factor productivity of EU new member states", Croatian Operational Research Review, Vol. 11 No. 2, pp. 263-273.

15. Khalifah, N. A. (2013), "Ownership and technical efficiency in Malaysia's automotive industry: A stochastic frontier production function analysis", The Journal of International Trade \& Economic Development, Vol. 22 No. 4, pp. 509-535.

16. Krammer, S. M. S. (2015), "Do good institutions enhance the effect of technological spillovers on productivity? Comparative evidence from developed and transition economies", Technological Forecasting and Social Change, Vol. 94 (May), pp. 133154.

17. Kravtsova, V. (2008), "Foreign presence and efficiency in transition economies", Journal of Productivity Analysis, Vol. 29 No. 2, pp. 91-102.

18. Ledeneva, A., Efendic, A. (2021), "The Rules of the Game in Transition: How Informal Institutions Work in South East Europe", in: Douarin, E., Havrylyshyn, O. (Eds.), The Palgrave Handbook of Comparative Economics, Springer, pp. 81 1-845.

19. Lemi, A., Wright, I. (2020), "Exports, foreign ownership, and firm-level efficiency in Ethiopia and Kenya: an application of the stochastic frontier model", Empirical Economics, Vol. 58 No. 2, pp. 669-698.

20. Lu, Y., Tao, Z., Zhu, L. (2017), "Identifying FDI spillovers", Journal of International Economics, Vol. 107, pp. 75-90.

21. Mazorodze, B. (2020), "Trade and efficiency of manufacturing industries in South Africa", The Journal of International Trade \& Economic Development, Vol. 29 No.1, pp. 89-118.

22. Mihaljek, D. (2018), "Convergence in Central and Eastern Europe: Can all get to the EU average?", Comparative Economic Studies, Vol. 60 No. 2, pp. 217-229.

23. Morris, D. M. (2018), "Innovation and productivity among heterogeneous firms", Research Policy, Vol. 47 No. 10, pp. 1918-1932.

24. Piesse, J., Thirtle, C. (2000), "A Stochastic Frontier Approach to Firm Level Efficiency, Technological Change, and Productivity during the Early Transition in Hungary", Journal of Comparative Economics, Vol. 28 No. 3, pp. 473-501.

25. Rodrik, D. (2017), "The illusive promise of structural reform", in Bournakis, I., Tsoukis, C., Christopoulos, D. K., Palivos. T. (Eds.), Political economy perspectives on the Greek Crisis, Palgrave Macmillan, Cham, pp. 61-70.

26. Rusu, V. D., Roman, A. (2017), "An empirical analysis of factors affecting competitiveness of CEE countries", Economic Research-Ekonomska istraživanja, Vol. 31 No. 1, pp. 2044-2059. 
27. Sandholtz, W., Taagepera, R. (2007), "Corruption, culture, and communism", International Review of Sociology: Revue Internationale de Sociologie, Vol. 15 No. 1 , pp. 109-131.

28. Sari, D. W., Khalifah, N. A., Suyanto, S. (2016), "The spillover effects of foreign direct investment on the firms' productivity performances", Journal of Productivity Analysis, Vol. 46 No. 2-3, pp. 199-233.

29. Stubelj, I., Dolenc, P., Biloslavo, R., Nahtigal, M., Laporšek, S. (2017), "Corporate purpose in a small post-transitional economy: the case of Slovenia", Economic Research-Ekonomska Istraživanja, Vol. 30 No. 1, pp. 818-835.

30. Todo, Y., Matous, P., Inove, H. (2016), "The strength of long ties and the weakness of strong ties: knowledge diffusion through supply chain networks", Research Policy, Vol. 45 No. 9, pp. 1890-1906.

31. Wagner, J. (2012), "International trade and firm performance: a survey of empirical studies since 2006", Review of World Economics, Vol. 148 No. 2, pp. 235-267.

32. Williams, C. C., Kedir, A. (2018), "Explaining cross-national variations in the prevalence of informal sector entrepreneurship: lessons from a survey of 142 countries", Journal of Development Entrepreneurship, Vol. 23 No. 1, pp.1-12.

\section{About the author}

Valerija Botric is a senior research fellow at The Institute of Economics Zagreb. She graduated from the University of Zagreb, where she got her Ph.D. with the topic "Inflation-unemployment relationship in Croatia." Her recent research interests include innovation, international trade, human capital. The author can be contacted at email vbotric@eizg.hr

\section{Appendix}

Table A 1

Factors Explaining Firm Inefficiency across Countries, Tobit Estimates

\begin{tabular}{|c|c|c|c|c|c|c|c|c|c|}
\hline Variables & Albania & B\&H & Croatia & Czechia & Estonia & $\begin{array}{l}\text { North } \\
\text { Maced. }\end{array}$ & Poland & Serbia & Slovenia \\
\hline Constant & $\begin{array}{c}0.243 \\
(0.264)\end{array}$ & $\begin{array}{c}0.113 \\
(0.117)\end{array}$ & $\begin{array}{c}0.190^{* * *} \\
(0.045)\end{array}$ & $\begin{array}{c}0.002 \\
(0.022)\end{array}$ & $\begin{array}{c}1.652^{* * *} \\
(0.146)\end{array}$ & $\begin{array}{c}0.203^{* * *} \\
(0.038)\end{array}$ & $\begin{array}{c}0.927^{* * *} \\
(0.100)\end{array}$ & $\begin{array}{c}1.452^{* * *} \\
(0.100)\end{array}$ & $\begin{array}{c}1.305^{* * *} \\
(0.116)\end{array}$ \\
\hline Firm age & $\begin{array}{c}0.003 \\
(0.003)\end{array}$ & $\begin{array}{c}0.006 * * * \\
(0.001)\end{array}$ & $\begin{array}{c}-0.001^{* *} \\
(0.000)\end{array}$ & $\begin{array}{l}0.001^{* *} \\
(0.001)\end{array}$ & $\begin{array}{l}-0.000 \\
(0.001)\end{array}$ & $\begin{array}{l}-0.000 \\
(0.001)\end{array}$ & $\begin{array}{l}-0.005 \\
(0.004)\end{array}$ & $\begin{array}{l}-0.001 \\
(0.001)\end{array}$ & $\begin{array}{c}-0.004^{* * *} \\
(0.001)\end{array}$ \\
\hline $\begin{array}{l}\text { Foreign } \\
\text { ownership }\end{array}$ & $\begin{array}{l}-0.014 \\
(0.118)\end{array}$ & $\begin{array}{c}0.140 \\
(0.093)\end{array}$ & $\begin{array}{c}-0.060^{* *} \\
(0.025)\end{array}$ & $\begin{array}{l}0.036^{* *} \\
(0.018)\end{array}$ & $\begin{array}{l}-0.123 \\
(0.104)\end{array}$ & $\begin{array}{c}0.024 \\
(0.039)\end{array}$ & $\begin{array}{c}-0.292^{* *} \\
(0.121)\end{array}$ & $\begin{array}{l}-0.131^{*} \\
(0.066)\end{array}$ & $\begin{array}{l}-0.123 \\
(0.091)\end{array}$ \\
\hline $\begin{array}{l}\text { Foreign } \\
\text { technology }\end{array}$ & $\begin{array}{c}0.07 \\
(0.204)\end{array}$ & $\begin{array}{c}-0.204^{* * *} \\
(0.063)\end{array}$ & $\begin{array}{c}-0.064^{* * *} \\
(0.020)\end{array}$ & $\begin{array}{c}0.020 \\
(0.017)\end{array}$ & $\begin{array}{c}0.076 \\
(0.107)\end{array}$ & $\begin{array}{l}-0.009 \\
(0.028)\end{array}$ & $\begin{array}{c}0.022 \\
(0.112)\end{array}$ & $\begin{array}{l}-0.002 \\
(0.087)\end{array}$ & $\begin{array}{l}-0.131^{*} \\
(0.071)\end{array}$ \\
\hline $\begin{array}{l}\text { International } \\
\text { certification }\end{array}$ & $\begin{array}{c}0.257 \\
(0.175)\end{array}$ & $\begin{array}{l}-0.089 \\
(0.066)\end{array}$ & $\begin{array}{c}-0.066^{* *} \\
(0.025)\end{array}$ & $\begin{array}{c}0.017 \\
(0.014)\end{array}$ & $\begin{array}{l}-0.162^{*} \\
(0.095)\end{array}$ & $\begin{array}{l}-0.014 \\
(0.025)\end{array}$ & $\begin{array}{l}-0.102 \\
(0.087)\end{array}$ & $\begin{array}{l}-0.067 \\
(0.088)\end{array}$ & $\begin{array}{c}-0.200^{* *} \\
(0.077)\end{array}$ \\
\hline Innovator & $\begin{array}{l}-0.193 \\
(0.125)\end{array}$ & $\begin{array}{l}0.169 * * \\
(0.069)\end{array}$ & $\begin{array}{c}0.020 \\
(0.025)\end{array}$ & $\begin{array}{l}0.027^{* *} \\
(0.012)\end{array}$ & $\begin{array}{c}0.010 \\
(0.088)\end{array}$ & $\begin{array}{l}-0.051^{*} \\
(0.028)\end{array}$ & $\begin{array}{c}0.066 \\
(0.070)\end{array}$ & $\begin{array}{l}-0.081 \\
(0.079)\end{array}$ & $\begin{array}{c}0.035 \\
(0.078)\end{array}$ \\
\hline Exporter & $\begin{array}{c}0.008^{* * *} \\
(0.002)\end{array}$ & $\begin{array}{l}0.002^{* *} \\
(0.001)\end{array}$ & $\begin{array}{c}-0.001^{* * *} \\
(0.000)\end{array}$ & $\begin{array}{c}0.001^{* * *} \\
(0.000)\end{array}$ & $\begin{array}{c}0.001 \\
(0.001)\end{array}$ & $\begin{array}{l}-0.000 \\
(0.000)\end{array}$ & $\begin{array}{c}-0.005^{* * *} \\
(0.001)\end{array}$ & $\begin{array}{c}0.000 \\
(0.001)\end{array}$ & $\begin{array}{c}-0.003^{* *} \\
(0.001)\end{array}$ \\
\hline $\begin{array}{l}\text { Government } \\
\text { contract }\end{array}$ & $\begin{array}{l}-0.170 \\
(0.192)\end{array}$ & $\begin{array}{c}0.023 \\
(0.093)\end{array}$ & $\begin{array}{l}-0.036 \\
(0.029)\end{array}$ & $\begin{array}{c}0.008 \\
(0.015)\end{array}$ & $\begin{array}{c}0.119 \\
(0.122)\end{array}$ & $\begin{array}{l}-0.043 \\
(0.031)\end{array}$ & $\begin{array}{l}-0.273^{*} \\
(0.153)\end{array}$ & $\begin{array}{c}0.072 \\
(0.069)\end{array}$ & $\begin{array}{l}-0.009 \\
(0.071)\end{array}$ \\
\hline $\begin{array}{l}\text { Informal } \\
\text { competitors }\end{array}$ & $\begin{array}{l}-0.054 \\
(0.142)\end{array}$ & $\begin{array}{c}0.049 \\
(0.074)\end{array}$ & $\begin{array}{l}-0.058^{*} \\
(0.035)\end{array}$ & $\begin{array}{l}-0.009 \\
(0.015)\end{array}$ & $\begin{array}{l}-0.028 \\
(0.104)\end{array}$ & $\begin{array}{c}0.008 \\
(0.026)\end{array}$ & $\begin{array}{c}0.056 \\
(0.106)\end{array}$ & $\begin{array}{l}-0.035 \\
(0.110)\end{array}$ & $\begin{array}{c}0.003 \\
(0.094)\end{array}$ \\
\hline $\begin{array}{l}\text { Manager } \\
\text { experience }\end{array}$ & $\begin{array}{l}0.014^{*} \\
(0.007)\end{array}$ & $\begin{array}{l}-0.004 \\
(0.004)\end{array}$ & $\begin{array}{c}0.002 \\
(0.002)\end{array}$ & $\begin{array}{l}-0.000 \\
(0.001)\end{array}$ & $\begin{array}{c}0.003 \\
(0.004)\end{array}$ & $\begin{array}{l}-0.001 \\
(0.002)\end{array}$ & $\begin{array}{l}-0.004 \\
(0.005)\end{array}$ & $\begin{array}{c}0.003 \\
(0.003)\end{array}$ & $\begin{array}{l}0.006^{* *} \\
(0.003)\end{array}$ \\
\hline $\operatorname{var}(e . u)$ & $\begin{array}{c}0.115^{* * *} \\
(0.023)\end{array}$ & $\begin{array}{c}0.030^{* * *} \\
(0.006)\end{array}$ & $\begin{array}{c}0.014^{* * *} \\
(0.005)\end{array}$ & $\begin{array}{c}0.007^{* * *} \\
(0.001)\end{array}$ & $\begin{array}{c}0.132^{* * *} \\
(0.027)\end{array}$ & $\begin{array}{c}0.003^{* * *} \\
(0.001)\end{array}$ & $\begin{array}{c}0.053^{* * *} \\
(0.011)\end{array}$ & $\begin{array}{l}0.045^{*} \\
(0.023)\end{array}$ & $\begin{array}{c}0.092^{* * *} \\
(0.012)\end{array}$ \\
\hline $\mathbf{N}$ & 40 & 37 & 104 & 189 & 76 & 29 & 40 & 41 & 100 \\
\hline
\end{tabular}

Source: author's estimates based on Enterprise Survey. 